\title{
PERSENTASE KERASIONALAN PENGGUNAAN ANTIBIOTIK \\ PADA PASIEN DEMAM TIFOID ANAK DI INSTALASI RAWAT INAP RUMAH SAKIT TK.II UDAYANA DENPASAR
}

\author{
(PERCENTAGE OF RATIONAL USE OF ANTIBIOTICS IN PEDIATRIC PATIENTS WITH \\ TYPHOID FEVER IN HOSPITALIZATION UNIT UDAYANA TK.II HOSPITAL)
}

\author{
FITRIA MEGAWATI ${ }^{1 *}$
}

\author{
${ }^{1}$ Akademi Farmasi Saraswati Denpasar, Jalan Kamboja no. 11A, Denpasar, Bali
}

\begin{abstract}
Abstrak: Demam tifoid merupakan suatu penyakit infeksi sistemik yang disebabkan oleh kuman Salmonella typhi. Menurut Hadinegoro (1999), insiden tertinggi demam tifoid terdapat pada anak-anak. Antibiotik merupakan terapi awal untuk penderita demam tifoid. Penggunaan antibiotik yang tidak rasional akan menimbulkan dampak negatif. Oleh karena itu, tujuan dari penelitian ini adalah untuk mengetahui persentase kerasionalan penggunaan antibiotik pada pasien demam tifoid anak di Instalasi Rawat Inap Rumah Sakit Tk.II Udayana Denpasar periode tahun 2013. Penelitian ini dikerjakan mengikuti rancangan deskriptif, data dikumpulkan secara retrospektif, dengan teknik pengambilan sampel purposive sampling. Penelitian dilakukan di Instalasi Rawat Inap Rumah Sakit Tk.II Udayana Denpasar pada pasien demam tifoid anak pada periode tahun 2013. Data rekam medis dianalisis kerasionalan penggunaan antibiotik dengan 3 parameter yaitu tepat indikasi, tepat obat dan tepat dosis. Hasil penelitian dari 60 pasien didapatkan bahwa persentase kerasionalan penggunaan antibiotik pada pasien demam tifoid anak sebesar 30,00\% dengan jumlah 18 pasien. Dapat disimpulkan bahwa persentase kerasionalan penggunaan antibiotik pada pasien demam tifoid anak sebesar $30,00 \%$.
\end{abstract}

Kata kunci: demam tifoid, anak, antibiotik, kerasionalan.

Abstract: Typhoid fever is a systemic infectious disease caused by Salmonella typhi. According to Hadinegoro (1999), the highest incidence of typhoid fever was found in children. Antibiotics are the initial therapy for patients with typhoid fever. Irrational use of antibiotics will have a negative impact. Therefore, the purpose of this study was to determine the percentage of rational use of antibiotics in hospitalization pediatric patients with typhoid fever in Udayana Tk.II Hospital in 2013 period. This study was undertaken following the descriptive design, data were collected retrospectively, the retrieval technique was purposive sampling. The study was conducted at the Udayana Tk.II Hospital in hospitalization pediatric patients with typhoid fever in 2013. The medical record of the pediatric patients were analyzed to see the rational use of antibiotics with three parameters, namely the right indication, the right medication and the right dosage. The results of the study of 60 pediatric patients found that the percentage of rational use of antibiotics in pediatric patients with typhoid fever was $30.00 \%$ with a number of 18 patients. It can be concluded that the percentage of rational use of antibiotics in pediatric patients with typhoid fever was $30.00 \%$.

Keywords: typhoid fever, pediatric, antibiotic, rational use.

\section{PENDAHULUAN}

Demam tifoid merupakan suatu penyakit infeksi sistemik yang disebabkan oleh Salmonella typhi. Demam tifoid ditemukan dalam kehidupan masyarakat, baik perkotaan maupun pedesaan. Penyakit demam tifoid erat kaitannya dengan hygiene dan sanitasi lingkungan seperti hygiene perseorangan dan hygiene makanan yang tidak sehat, lingkungan yang kumuh, kebersihan tempattempat umum yang kurang serta perilaku masyarakat yang tidak mendukung untuk hidup sehat. Demam tifoid bersifat endemik dan merupakan masalah kesehatan masyarakat sehingga penyakit demam tifoid harus mendapatkan perhatian serius karena permasalahannya yang sangat kompleks sehingga menyulitkan upaya pengobatan dan pencegahan. Demam tifoid adalah penyakit infeksi akut yang biasanya mengenai saluran cerna dengan gejala demam lebih dari 7 hari, gangguan pada saluran cerna, dan gangguan kesadaran (Mansjoer dkk, 2000).

\footnotetext{
* Penulis Korespondensi, Hp. 081229913010

e-mail: f.mega83@gmail.com
} 
Kasus demam tifoid di rumah sakit besar di Indonesia menunjukkan angka kesakitan cenderung meningkat setiap tahun dengan rata-rata 500/100.000 penduduk. Angka kematian diperkirakan sekitar 0,6-5\% sebagai akibat dari keterlambatan mendapatkan pengobatan serta tingginya biaya pengobatan (Menkes, 2006).

Menurut Soepardi dkk. (2011) menyatakan bahwa pada profil kesehatan Indonesia tahun 2010 demam tifoid menempati urutan ke-3 dari 10 penyakit terbanyak pasien rawat inap di rumah sakit yaitu sebanyak 41.081 kasus, yang meninggal 274 orang dengan Case Fatality Rate sebesar 0,67\%. Insiden tertinggi demam tifoid terdapat pada anakanak. Demam tifoid pada anak terbanyak terjadi pada kelompok umur 5 tahun atau lebih dan mempunyai manifestasi klinis yang ringan (Hadinegoro, 1999).

Tatalaksana pengobatan demam tifoid antara lain perawatan umum dan nutrisi meliputi tirah baring, pemberian cairan, makan-makanan lunak yang rendah serat, dan terapi simptomatik.

Demam tifoid disebabkan karena infeksi kuman Salmonella typhi sehingga terapi awal diberikan antibiotik. Penggunaan antibiotik tentu diharapkan mempunyai dampak positif. Penggunaan antibiotik yang tidak rasional akan menimbulkan dampak negatif. Dampak negatif dari penggunaan antibiotik yang tidak rasional antara lain muncul bakteri yang resisten terhadap antibiotik, munculnya penyakit akibat superinfeksi bakteri resisten, terjadinya toksisitas/efek samping obat.

Masalah resistensi bakteri terhadap antibiotik bukanlah masalah pribadi suatu negara saja, tetapi sudah menjadi masalah kesehatan di seluruh dunia. Masalah global yang sedang dihadapi ini perlu ditanggulangi bersama. Salah satu cara mengatasinya ialah dengan menggunakan antibiotik secara rasional, melakukan monitoring dan evaluasi penggunaan antibiotik di rumah sakit secara sistematis, terstandar dan dilaksanakan secara teratur di rumah sakit ataupun di pusat kesehatan masyarakat, dan melakukan intervensi untuk mengoptimalkan penggunaan antibiotik (Wilianti, 2009).

Berdasarkan latar belakang di atas rumusan masalah pada penelitian ini adalah: "Berapa persentase kerasionalan penggunaan antibiotik yang meliputi tepat indikasi, tepat obat, dan tepat dosis pada pasien demam tifoid anak di Instalasi Rawat Inap Rumah Sakit Tk.II Udayana Denpasar periode tahun 2013?'”

\section{METODOLOGI PENELITIAN}

Tempat dan Waktu Penelitian. Penelitian ini dilakukan di bagian rekam medik Rumah Sakit TK. II Udayana Denpasar, pada bulan Februari 2014 dengan mengambil data periode tahun 2013.

Jenis Penelitian. Penelitian ini termasuk dalam jenis penelitian deskriptif dengan pengambilan data secara retrospektif yang didasarkan pada catatan rekam medis.

Populasi dan Sampel Penelitian. Populasi dalam penelitian ini ialah semua catatan medis pasien pasien anak dengan diagnosa demam tifoid yang mendapatkan antibiotik di Instalasi Rawat Inap Rumah Sakit Tk. II Udayana Denpasar periode 1 Januari sampai 31 Desember 2013. Adapun jumlah populasi yang didapat sebanyak 72 pasien. Sampel dalam penelitian Sampel penelitian adalah sejumlah pasien anak dengan diagnosa demam tifoid yang mendapatkan antibiotik yang memenuhi kriteria penelitian. Adapun sampel dalam penelitian ini sebanyak 60 pasien.

Kriteria Penelitian. Tepat Indikasi, Tepat Obat, Tepat Dosis.

Pengumpulan Data. Rekam medis data yang diambil meliputi nama pasien, jenis kelamin pasien, umur pasien, berat badan pasien, jenis antibiotik dan dosis penggunaan antibiotik. Pengumpulan data dimulai dengan penelusuran data dari laporan unit rekam medik untuk pasien anak dengan diagnosis demam tifoid yang dirawat inap periode 1 Januari sampai 31 Desember 2013. Data yang diambil dibuat dalam tabulasi yang meliputi nomor rekam medik, umur, jenis kelamin, berat badan, diagnosis, terapi antibiotika, dosis, dan kondisi pulang.

Analisis Data. Data penggunaan antibiotika pada penderita demam tifoid anak yang dirawat nap di RS Tingkat II Udayana tahun 2013 dianalisis secara deskriptif untuk menjelaskan kerasionalan penggunaan antibiotika yang diterima pasien selama dirawat inap. Adapun standar pengobatan yang digunakan sebagai pembanding dalam penelitian ini yakni Keputusan Menteri Kesehatan Republik Indonesia Nomor 364/Menkes/SK/V/2006 tentang pedoman pengendalian demam tifoid. 


\section{HASIL DAN PEMBAHASAN}

Karakteristik Demografi Berdasarkan Jenis Kelamin

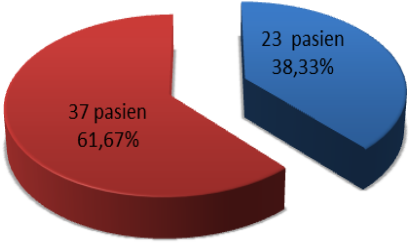

四ki-laki

घperempuan

Gambar 1 Karakteristik Demografi Pasien Berdasarkan Jenis Kelamin Pasien Demam Tifoid Anak di Instalasi Rawat Inap Rumah Sakit Tk.II Udayana Denpasar Periode Tahun 2013

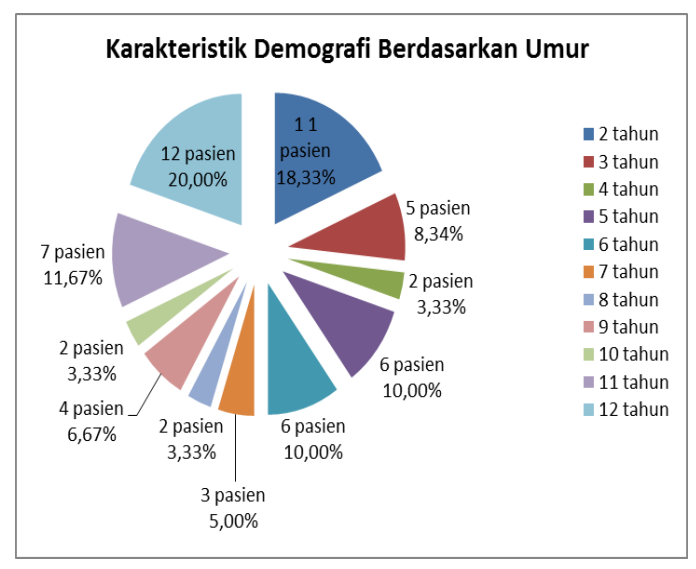

Gambar 2. Karakteristik Demografi Pasien Berdasarkan Umur Pasien Demam Tifoid Anak di Instalasi Rawat Inap Rumah Sakit Tk.II Udayana Denpasar Periode Tahun 2013

Tabel 1. Karakteristik Demografi Pasien Berdasarkan Berat Badan Pasien Demam Tifoid Anak di Instalasi Rawat Inap Rumah Sakit Tk.II Udayana Denpasar Periode Tahun 2013

\begin{tabular}{|c|c|c|c|}
\hline No & $\begin{array}{c}\text { Berat } \\
\text { Badan (kg) }\end{array}$ & Jumlah & $\begin{array}{c}\text { Persentase } \\
(\mathbf{\%})\end{array}$ \\
\hline 1 & $8-13$ & 15 & 25,00 \\
\hline 2 & $14-19$ & 9 & 15,00 \\
\hline 3 & $20-25$ & 9 & 15,00 \\
\hline 4 & $26-31$ & 10 & 16,67 \\
\hline 5 & $32-37$ & 7 & 11,67 \\
\hline 6 & $38-43$ & 6 & 10,00 \\
\hline 7 & $44-49$ & 4 & 6,66 \\
\hline \multicolumn{2}{r}{ Total } & $\mathbf{6 0}$ & $\mathbf{1 0 0 , 0 0}$ \\
\hline
\end{tabular}

Tabel 2. Tabel Antibiotik Yang Digunakan Check List Berdasarkan Keterangan penggunaan antibiotik berdasarkan tepat indikasi, tepat obat dan tepat dosis

\begin{tabular}{|c|c|c|c|}
\hline No & $\begin{array}{c}\text { Antibiotik } \\
\text { Generik }\end{array}$ & $\begin{array}{c}\text { Antibiotik yang } \\
\text { Digunakan }\end{array}$ & Dosis \\
\hline 1. & TFK & $\begin{array}{l}\text { Thyamicin } 500 \\
\text { cap }\end{array}$ & $3 \times 500 \mathrm{mg}$ \\
\hline 2. & SFR & Starxon inj & $1 \times 750 \mathrm{mg}$ \\
\hline 3. & TFK & Thyamicin F syr & $3 \times 1 \frac{1}{2} \mathrm{cth}$ \\
\hline 4. & SFR & Starxon inj & $2 \times 1 \mathrm{~g}$ \\
\hline 5. & SFT & Lapixime inj & $3 \times 500 \mathrm{mg}$ \\
\hline 6. & SFZ & Ezox inj & $3 \times 200 \mathrm{mg}$ \\
\hline 7. & SFR & Starxon inj & $1 \times 1 \mathrm{~g}$ \\
\hline 8. & SFT & Lapixime inj & $3 \times 1 \mathrm{~g}$ \\
\hline 9. & SFR & Terfcef inj & $1 \times 750 \mathrm{mg}$ \\
\hline 10. & SFR & Cefxon inj & $2 \times 750 \mathrm{mg}$ \\
\hline 11. & SFT & Lapixime inj & $3 \times 400 \mathrm{mg}$ \\
\hline 12. & SFZ & Ezox inj & $3 \times 1 / 3$ vial \\
\hline 13. & SFZ & Ezox inj & $3 \times 200 \mathrm{mg}$ \\
\hline 14. & SFR & Starxon Inj & $1 \times 500 \mathrm{mg}$ \\
\hline 15. & TFK & $\begin{array}{l}\text { Thyamicin } 500 \\
\text { cap }\end{array}$ & $3 \times 500 \mathrm{mg}$ \\
\hline 16. & TFK & $\begin{array}{l}\text { Tiamfenikol } 500 \\
\text { cap }\end{array}$ & $3 \times 500 \mathrm{mg}$ \\
\hline 17. & SFR & Seftriakson inj & $1 \times 2 g$ \\
\hline 18. & SFR & Seftriakson inj & $2 \times 1 \mathrm{~g}$ \\
\hline 19. & SFT & Rycef inj & $2 \times 700 \mathrm{mg}$ \\
\hline 20. & TFK & Tiamfenikol cap & $4 \times 500 \mathrm{mg}$ \\
\hline 21. & SFT & Sefotaksim Inj & $3 \times 1 / 2$ vial \\
\hline 22. & SFR & Seftriakson Inj & $1 \times 500 \mathrm{mg}$ \\
\hline 23. & TFK & $\begin{array}{l}\text { Tiamfenikol } 500 \\
\text { Cap }\end{array}$ & $3 \times 400 \mathrm{mg}$ \\
\hline 24. & SFR & Seftriakson Inj & $2 \times 600 \mathrm{mg}$ \\
\hline 25. & SFS & Sefiksim Syr & $2 \times 3 / 4$ cth \\
\hline 26. & SFR & Sefriakson Inj & $2 \times 1 \mathrm{~g}$ \\
\hline 27. & SFR & Starxon Inj & $2 \times 750 \mathrm{mg}$ \\
\hline 28. & SFR & Cefxon Inj & $1 \times 750 \mathrm{mg}$ \\
\hline 29. & SFS & Sefiksim Syr & $2 \times 1 \mathrm{cth}$ \\
\hline 30. & SFT & Sefotaksim Inj & $3 \times 900 \mathrm{mg}$ \\
\hline 31. & TFK & Tiamfenikol Cap & $3 \times 500 \mathrm{mg}$ \\
\hline 32. & TFK & Tiamfenikol Cap & $3 \times 500 \mathrm{mg}$ \\
\hline 33. & SFR & Seftriakson Inj & $2 \times 1 \mathrm{~g}$ \\
\hline 34. & TFK & Thyamicin F Syr & $3 \times 13 / 4$ cth \\
\hline 35. & SFD & Sefadroksil Syr & $\begin{array}{l}2 \times 11 / 3 \\
\text { cth }\end{array}$ \\
\hline 36. & TFK & Thyamicin Syr & $3 \times 1 \mathrm{cth}$ \\
\hline 37. & KTM & $\begin{array}{l}\text { Kotrimoksasol } \\
\text { Tab }\end{array}$ & $2 \times 1$ \\
\hline 38. & SFR & Seftriakson Inj & $2 \times 750 \mathrm{mg}$ \\
\hline 39. & SFS & Sefiksim Syr & $2 \times 1 / 2$ cth \\
\hline 40. & TFK & Thyamicin F Syr & $3 \times 11 / 2$ cth \\
\hline 41. & TFK & Thyamicin F Syr & $4 \times 1 \mathrm{cth}$ \\
\hline 42. & SFR & Starxon Inj & $1 \times 1 \mathrm{~g}$ \\
\hline 43. & SFR & Seftriakson Inj & $1 \times 800 \mathrm{mg}$ \\
\hline 44. & TFK & Tiamfenikol Cap & $3 \times 500 \mathrm{mg}$ \\
\hline 45. & TFK & Thyamicin Syr & $3 \times 13 / 4 \mathrm{cth}$ \\
\hline 46. & TFK & Thyamicin Tab & $4 \times 500 \mathrm{mg}$ \\
\hline 47. & SFR & Starxon Inj & $1 \times 1 \mathrm{~g}$ \\
\hline
\end{tabular}




\begin{tabular}{|l|c|l|l|}
\hline No & $\begin{array}{c}\text { Antibiotik } \\
\text { Generik }\end{array}$ & $\begin{array}{c}\text { Antibiotik yang } \\
\text { Digunakan }\end{array}$ & \multicolumn{1}{|c|}{ Dosis } \\
\hline 48. & SFR & Starxon Inj & $1 \times 1 \mathrm{~g}$ \\
\hline 49. & TFK & Thyamicin F Syr & $3 \times 13 / 4 \mathrm{cth}$ \\
\hline 50. & TFK & Thyamicin F Syr & $3 \times 1 \frac{1}{2} \mathrm{cth}$ \\
\hline 51. & TFK & Tiampenikol Cap & $4 \times 500 \mathrm{mg}$ \\
\hline 52. & SFD & Sefadroksil Syr & $2 \times 500 \mathrm{mg}$ \\
\hline 53. & TFK & Tiampenikol Cap & $4 \times 1$ \\
\hline 54. & TFK & Thyamicin F Syr & $3 \times 11 / 2 \mathrm{cth}$ \\
\hline 55. & TFK & Thyamicin Syr & $4 \times 1 \mathrm{cth}$ \\
\hline 56. & SFR & Seftriakson Inj & $2 \times 1 \mathrm{~g}$ \\
\hline 57. & SFT & Lapixime Inj & $3 \times 400 \mathrm{mg}$ \\
\hline
\end{tabular}

\begin{tabular}{|c|c|l|l|}
\hline No & $\begin{array}{c}\text { Antibiotik } \\
\text { Generik }\end{array}$ & $\begin{array}{c}\text { Antibiotik yang } \\
\text { Digunakan }\end{array}$ & \multicolumn{1}{|c|}{ Dosis } \\
\hline 58. & SFT & Lapixime injeksi & $4 \times 1 \mathrm{~g}$ \\
\hline 59. & SFT & Rycef injeksi & $2 \times 700 \mathrm{mg}$ \\
\hline 60. & TFK & $\begin{array}{l}\text { Tiampenikol } \\
\text { capsul }\end{array}$ & $4 \times 500 \mathrm{mg}$ \\
\hline
\end{tabular}

Ket:TFK: Tiamfenikol; SFR: Seftriakson; SFZ: Seftizoksim; SFD: Sefadroxil; SFT: Sefotaxim; SFS: Sefiksim; KTM: Kotrimoksasol

Tabel 3. Check List Berdasarkan Keterangan penggunaan antibiotik berdasarkan tepat indikasi, tepat obat dan tepat dosis

\begin{tabular}{|c|c|c|c|c|c|c|c|}
\hline No & $\begin{array}{c}\text { Antibiotik } \\
\text { Generik }\end{array}$ & $\begin{array}{l}\text { Antibiotik yang } \\
\text { Digunakan }\end{array}$ & $\begin{array}{c}\text { Tepat } \\
\text { Indikasi }\end{array}$ & $\begin{array}{l}\text { Tepat } \\
\text { Obat }\end{array}$ & $\begin{array}{l}\text { Tepat } \\
\text { Dosis }\end{array}$ & Kerasionalan & $\begin{array}{c}\text { Ketidak } \\
\text { Rasionalan }\end{array}$ \\
\hline 1. & TFK & Thyamicin 500 Cap & $\sqrt{ }$ & $\sqrt{ }$ & - & - & $\sqrt{ }$ \\
\hline 2. & SFR & Starxon Inj & $\sqrt{ }$ & $\sqrt{ }$ & - & - & $\sqrt{ }$ \\
\hline 3. & TFK & Thyamicin F.Syr & $\sqrt{ }$ & $\sqrt{ }$ & - & - & $\sqrt{ }$ \\
\hline 4. & SFR & Starxon Inj & $\sqrt{ }$ & $\sqrt{ }$ & $\sqrt{ }$ & $\sqrt{ }$ & - \\
\hline 5. & SFT & Lapixime Inj & $\sqrt{ }$ & - & $\sqrt{ }$ & - & $\sqrt{ }$ \\
\hline 6. & SFZ & Ezox Inj & $\sqrt{ }$ & - & - & - & $\sqrt{ }$ \\
\hline 7. & SFR & Starxon Inj & $\sqrt{ }$ & $\sqrt{ }$ & - & - & $\sqrt{ }$ \\
\hline 8. & SFT & Lapixime Inj & $\sqrt{ }$ & - & - & - & $\sqrt{ }$ \\
\hline 9. & SFR & Terfacef Inj & $\sqrt{ }$ & $\sqrt{ }$ & - & - & $\sqrt{ }$ \\
\hline 10. & SFR & Cefxon Inj & $\sqrt{ }$ & $\sqrt{ }$ & - & - & $\sqrt{ }$ \\
\hline 11. & SFT & Lapixime Inj & $\sqrt{ }$ & - & - & - & $\sqrt{ }$ \\
\hline 12. & SFZ & Ezox Inj & $\sqrt{ }$ & - & - & - & $\sqrt{ }$ \\
\hline 13. & SFZ & Ezox Inj & $\sqrt{ }$ & - & - & - & $\sqrt{ }$ \\
\hline 14. & SFR & Starxon Inj & $\sqrt{ }$ & $\sqrt{ }$ & - & - & $\sqrt{ }$ \\
\hline 15. & TFK & Thyamicin 500 Cap & $\sqrt{ }$ & $\sqrt{ }$ & $\sqrt{ }$ & $\sqrt{ }$ & - \\
\hline 16. & TFK & Tiamfenikol 500 Cap & $\sqrt{ }$ & $\sqrt{ }$ & - & - & $\sqrt{ }$ \\
\hline 17. & SFR & Seftriakson Inj & $\sqrt{ }$ & $\sqrt{ }$ & - & - & $\sqrt{ }$ \\
\hline 18. & SFR & Seftriakson Inj & $\sqrt{ }$ & $\sqrt{ }$ & - & - & $\sqrt{ }$ \\
\hline 19. & SFT & Rycef.Inj & $\sqrt{ }$ & - & - & - & $\sqrt{ }$ \\
\hline 20. & TFK & Tiamfenikol Cap & $\sqrt{ }$ & $\sqrt{ }$ & $\sqrt{ }$ & $\sqrt{ }$ & - \\
\hline 21. & SFT & Sefotaksim Inj & $\sqrt{ }$ & - & $\sqrt{ }$ & - & $\sqrt{ }$ \\
\hline 22. & SFR & Sefriakson Inj & $\sqrt{ }$ & $\sqrt{ }$ & - & - & $\sqrt{ }$ \\
\hline 23. & TFK & Tiamfenikol 500 Cap & $\sqrt{ }$ & $\sqrt{ }$ & $\sqrt{ }$ & $\sqrt{ }$ & - \\
\hline 24. & SFR & Sefriakson Inj & $\sqrt{ }$ & $\sqrt{ }$ & $\sqrt{ }$ & $\sqrt{ }$ & - \\
\hline 25. & SFS & Sefiksim Syr & $\sqrt{ }$ & $\sqrt{ }$ & - & - & $\sqrt{ }$ \\
\hline 26. & SFR & Seftriakson Inj & $\sqrt{ }$ & $\sqrt{ }$ & - & - & $\sqrt{ }$ \\
\hline 27. & SFR & Starxon Inj & $\sqrt{ }$ & $\sqrt{ }$ & - & - & $\sqrt{ }$ \\
\hline 38. & SFR & Cefxon Inj & $\sqrt{ }$ & $\sqrt{ }$ & $\sqrt{ }$ & $\sqrt{ }$ & - \\
\hline 39. & SFS & Sefiksim Syr & $\sqrt{ }$ & $\sqrt{ }$ & - & - & $\sqrt{ }$ \\
\hline 30. & SFT & Sefotaksim Inj & $\sqrt{ }$ & - & $\sqrt{ }$ & - & $\sqrt{ }$ \\
\hline 31. & TFK & Tiamfenikol Cap & $\sqrt{ }$ & $\sqrt{ }$ & - & - & $\sqrt{ }$ \\
\hline 32. & TFK & Tiamfenikol Cap & $\sqrt{ }$ & $\sqrt{ }$ & - & - & $\sqrt{ }$ \\
\hline 33. & SFR & Seftriakson Inj & $\sqrt{ }$ & $\sqrt{ }$ & $\sqrt{ }$ & $\sqrt{ }$ & - \\
\hline 34. & TFK & Thyamicin F Syr & $\sqrt{ }$ & $\sqrt{ }$ & $\sqrt{ }$ & $\sqrt{ }$ & - \\
\hline 35. & SFD & Sefadroksil Syr & $\sqrt{ }$ & - & - & - & $\sqrt{ }$ \\
\hline 36. & TFK & Thyamicin Syr & $\sqrt{ }$ & $\sqrt{ }$ & - & - & $\sqrt{ }$ \\
\hline 37. & KTM & Kotrimoksasol Tab & $\sqrt{ }$ & $\sqrt{ }$ & - & - & $\sqrt{ }$ \\
\hline 38. & SFR & Seftriakson Inj & $\sqrt{ }$ & $\sqrt{ }$ & - & - & $\sqrt{ }$ \\
\hline 39. & SFS & Sefiksim Syr & $\sqrt{ }$ & $\sqrt{ }$ & - & - & $\sqrt{ }$ \\
\hline
\end{tabular}




\begin{tabular}{|c|c|c|c|c|c|c|c|}
\hline 40. & TFK & Thyamicin F Syr & $\sqrt{ }$ & $\sqrt{ }$ & - & - & $\sqrt{ }$ \\
\hline 41. & TFK & Thyamicin F Syr & $\sqrt{ }$ & $\sqrt{ }$ & $\sqrt{ }$ & $\sqrt{ }$ & - \\
\hline 42. & SFR & Starxon Inj & $\sqrt{ }$ & $\sqrt{ }$ & - & - & $\sqrt{ }$ \\
\hline 43. & SFR & Sefriakson Inj & $\sqrt{ }$ & $\sqrt{ }$ & - & - & $\sqrt{ }$ \\
\hline 44. & TFK & Tiamfenikol Cap & $\sqrt{ }$ & $\sqrt{ }$ & - & - & $\sqrt{ }$ \\
\hline 45. & TFK & Thyamicin Syr & $\sqrt{ }$ & $\sqrt{ }$ & $\sqrt{ }$ & $\sqrt{ }$ & - \\
\hline 46. & TFK & Thyamicin Tab & $\sqrt{ }$ & $\sqrt{ }$ & $\sqrt{ }$ & $\sqrt{ }$ & - \\
\hline 47. & SFR & Starxon Inj & $\sqrt{ }$ & $\sqrt{ }$ & $\sqrt{ }$ & $\sqrt{ }$ & - \\
\hline 48. & SFR & Starxon Inj & $\sqrt{ }$ & $\sqrt{ }$ & - & - & $\sqrt{ }$ \\
\hline 49. & TFK & Thyamicin F Syr & $\sqrt{ }$ & $\sqrt{ }$ & - & - & $\sqrt{ }$ \\
\hline 50. & TFK & Thyamicin F Syr & $\sqrt{ }$ & $\sqrt{ }$ & $\sqrt{ }$ & $\sqrt{ }$ & - \\
\hline 51. & TFK & Tiampenikol Cap & $\sqrt{ }$ & $\sqrt{ }$ & $\sqrt{ }$ & $\sqrt{ }$ & - \\
\hline 52. & SFD & Sefadroksil Syr & $\sqrt{ }$ & - & - & - & $\sqrt{ }$ \\
\hline 53. & TFK & Tiampenikol Cap & $\sqrt{ }$ & $\sqrt{ }$ & $\sqrt{ }$ & $\sqrt{ }$ & - \\
\hline 54. & TFK & Thyamicin F Syr & $\sqrt{ }$ & $\sqrt{ }$ & $\sqrt{ }$ & $\sqrt{ }$ & - \\
\hline 55. & TFK & Thyamicin Syr & $\sqrt{ }$ & $\sqrt{ }$ & - & - & $\sqrt{ }$ \\
\hline 56. & SFR & Seftriakson Inj & $\sqrt{ }$ & $\sqrt{ }$ & $\sqrt{ }$ & $\sqrt{ }$ & - \\
\hline 57. & SFT & Lapixime Inj & $\sqrt{ }$ & - & - & - & $\sqrt{ }$ \\
\hline 58. & SFT & Lapixime Inj & $\sqrt{ }$ & - & $\sqrt{ }$ & - & $\sqrt{ }$ \\
\hline 59. & SFT & Rycef Inj & $\sqrt{ }$ & - & $\sqrt{ }$ & - & $\sqrt{ }$ \\
\hline 60. & TFK & Tiampenikol Cap & $\sqrt{ }$ & $\sqrt{ }$ & $\sqrt{ }$ & $\sqrt{ }$ & - \\
\hline \multicolumn{5}{|c|}{ Total } & \multicolumn{2}{|c|}{18} & 42 \\
\hline \multicolumn{5}{|c|}{ Persentase (\%) } & \multicolumn{2}{|c|}{30,00} & 70,00 \\
\hline
\end{tabular}

\section{Kerasionalan Penggunaan Antibiotik}

- Kerasionalan $\square$ ketidakrasionalan

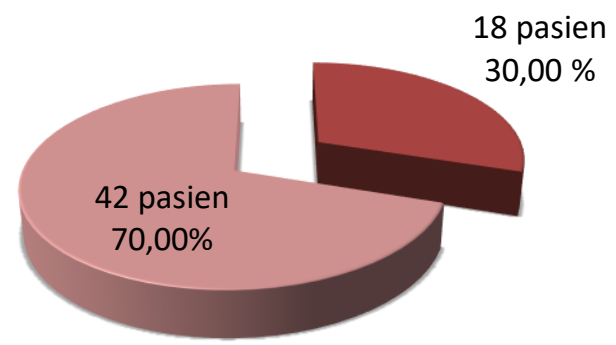

Gambar 3. Diagram kerasionalan penggunaan antibiotik berdasarkan tepat indikasi, tepat obat dan tepat dosis

Setelah dilakukan penelusuran data melalui rekam medis di Rumah Sakit Tk.II Udayana Denpasar periode tahun 2013 jumlah pasien anak dengan diagnosa demam tifoid adalah sebanyak 72 pasien. Dari 72 pasien dilakukan penelusuran data yang memenuhi kriteria inklusi dan tidak memenuhi kriteria eksklusi sebanyak 60 pasien.

Dari hasil penelitian menunjukkan bahwa demam tifoid lebih banyak diderita oleh perempuan sebesar $61,67 \%$ dengan jumlah 37 pasien. Hal ini sesuai dengan penelitian yang dilakukan oleh Djatmiko dkk.(2007) menyatakan bahwa demam tifoid lebih banyak diderita oleh perempuan. Hasil ini berbeda penelitian yang dilakukan oleh Widyasih (2009) yang mengatakan bahwa demam tifoid lebih banyak diderita oleh laki - laki. Hasil penelitian tidak bisa disimpulkan bahwa ada pengaruh jenis kelamin dengan demam tifoid. Terjadinya insiden demam tifoid dipengaruhi oleh sistem kekebalan tubuh, pola makan, status gizi, keadaan hygiene dan sanitasi lingkungan.

Usia kejadian demam tifoid yang paling banyak diderita pada pasien yang berumur 12 tahun sebesar 20,00\% dengan jumlah 12 pasien. Menurut WHO (2003), di Indonesia orang yang berumur 319 tahun menyumbang $91 \%$ dari kasus demam 
tifoid. Ini menunjukkan bahwa pada umur 12 tahun adalah umur rawan terjangkitnya demam tifoid karena pada umur tersebut adalah umur anak sekolah dan biasanya mereka masih menyukai membeli makanan dan minuman di lingkungan sekolah dan dipinggir jalan yang tidak hygiene. Lingkungan tersebut berperan besar dalam penyebaran kuman Salmonella typhi.

Pasien yang memiliki kelompok berat badan antara 8-13 kg paling banyak menderita demam tifoid sebesar $25,00 \%$ dengan jumlah 15 pasien. Dilihat dari kelompok berat badan $8-13 \mathrm{~kg}$, kelompok berat badan tersebut merupakan anak balita. Menurut Nainggolan (2010), anak balita mengalami pertumbuhan badan yang pesat sehingga memerlukan zat-zat gizi yang tinggi setiap kilogram berat badannya dan sering menderita penyakit infeksi akibat kekurangan gizi sehingga kekebalan tubuh melemah. Berat badan juga menentukan dalam perhitungan dosis terutama pada anak-anak.

Penelitian ini dilakukan dengan mengamati kerasionalan penggunaan antibiotik dengan menggunakan 3 parameter yaitu tepat indikasi, tepat obat dan tepat dosis untuk masing-masing pasien. Apabila salah satu dari parameter tersebut tidak sesuai maka dikatakan tidak rasional. Hasil penelitian dari 60 pasien didapatkan bahwa persentase kerasionalan penggunaan antibiotik untuk pasien demam tifoid anak sebesar $30,00 \%$ dengan jumlah 18 pasien.

Seluruh pasien masuk kategori tepat indikasi. Dikatakan tepat indikasi apabila pasien mendapatkan terapi antibiotik dengan indikasi yang jelas bahwa pasien menderita demam tifoid dengan adanya hasil pemeriksaan laboratorium. Pemeriksaan laboratorium untuk demam tifoid dengan uji widal. Menurut Borong (2011), berdasarkan literatur bahwa untuk memberikan antibiotik harus berdasarkan pemeriksaan laboratorium.

Tepat obat ini berarti obat yang dipilih harus memiliki efek terapi dari suatu penyakit. Tepat obat mengacu pada Keputusan Menteri Kesehatan Republik Indonesia Nomor 364/Menkes/SK/V/2006 tentang pedoman pengendalian demam tifoid mengatakan bahwa terapi antibiotik yang digunakan adalah kloramfenikol, seftriakson, ampisilin dan amoksisilin, kotrimoksasol, golongan quinolone (siprofloksasin, ofloksasin, pefloksasin dan freloksasin), sefiksim dan thiamfenikol. Jenis antibiotik ini digunakan untuk infeksi dengan kuman gram negatif (Salmonella typhi).

Jenis antibiotik yang tepat obat adalah thiamfenikol, seftriakson, sefiksim dan kotrimoksasol sedangkan yang tidak tepat obat adalah sefadroksil, sefotaksim dan seftizoksim. Menurut Tan Hoan Tjay dan Rahardja K (2007), sefadroksil merupakan golongan antibiotik sefalosporin generasi kedua yang aktif terhadap kuman gram positif sedangkan demam tifoid disebabkan oleh kuman gram negatif. Walaupun sefotaksim dan seftizoksim digunakan untuk infeksi kuman gram negatif tetapi jenis antibiotik ini tidak termasuk dalam Keputusan Menteri Kesehatan Republik Indonesia Nomor 364/Menkes/SK/V/2006 tentang pedoman pengendalian demam tifoid.

Kriteria tepat dosis berpedoman pada Menkes (2006), British National Formulary (BNF) tahun 2008, Drug Information Handbook (DIH) tahun 2008 - 2009. Ketidaktepatan dosis diklasifikasikan menjadi dua yaitu dosis berlebihan dan dosis yang kurang.

\section{SIMPULAN}

Simpulan. Berdasarkan hasil penelitian mengenai kerasionalan penggunaan antibiotik pada pasien demam tifoid anak di Instalasi Rawat Inap Rumah Sakit Tk.II Udayana Denpasar dapat disimpulkan bahwa persentase kerasionalan penggunaan antibiotik berdasarkan tepat indikasi, tepat obat dan tepat dosis sebesar $30,00 \%$.

\section{DAFTAR PUSTAKA}

Anonim, 2012, British National Formulary, edisi 56, London, Royal Pharmaceutical Society.

Aslam Mohamed, Tan Kaw C, Prayitno A, 2003, Farmasi Klinis (Clinical Pharmacy) Menuju Pengobatan Rasional dan Penghargaan Pilihan Pasien, PT Elex Media Komputindo Kelompok Gramedia, Jakarta, 191-192.

Borong Meyta Fransiska, Kerasionalan Penggunaan Antibiotik pada Pasien Rawat Inap Anak Rumah Sakit M.M Dunda Limbto Tahun 2011, Gorontalo, Fakultas Ilmu-Ilmu Kesehatan dan Keolahragaan, (online), (ejurnal.fikk.ung.ac.id/index.php/FSC/article /download/78/31 diakses 09 Juli 2014)

Direktorat Bina Penggunaan Obat Rasional tentang Materi Pelatihan Peningkatan Pengetahuan dan Keterampilan Memilih Obat Bagi Tenaga Kesehatan, 2008, Jakarta, Direktorat Jendral Bina Kefarmasian dan Alat Kesehatan Departemen Kesehatan Republik Indonesia, (online), (binfar.depkes.go.id/dat/lama/1276164586_ MODUL\%20_I.pd diakses 09 juli 2014) 
Djatmiko M, Sugiyanti, Anas Y, Analisis Biaya dan Gambaran Penggunaan Antibiotik Pada Pasien Demam Tifoid Rawat Inap di Puskesmas Tlogorsari Kulon Tahun 2007, Semarang, Fakultas Farmasi Universitas Wahid Hasyim Semarang, (online),(http://www.unwahas.ac.id/publikas iilmiah/index.php/ilmuFarmasidanklinik/arti cle/view/820 diakses 09 Juli 2014)

Hadinegoro Sri Rejeki, 1999, Cermin Dunia Kedokteran, Masalah Multi Drug Resistance pada Demam Tifoid Anak,124-5, (online), (http://www. Multi Drug Resistance .go.id diakses 2 Januari 2014)

Keputusan Menteri Kesehatan Republik Indonesia Nomor 364/Menkes/SK/V/2006 tentang Pedoman Pengendalian Demam Tifoid, 2006, Jakarta: Menteri Kesehatan Republik Indonesia

Keputusan Menteri Kesehatan Republik Indonesia Nomor 1197/SK/X/2009 tentang Standar Pelayanan Farmasi di Rumah Sakit, 2009, Jakarta: Menteri Kesehatan Republik Indonesia

Lacy. F Charles, Amstrong L.Lora, Goldman.P. Morton, Lance L. Leonard, 2009-2010, Drug Information Handbook, edisi 17, Lexicomp, Amerika

Mansjoer Arif, Suprohaita, Wardhani WI, Setiowulan, Wicaksono A, Hamsah, dkk., 2000, Kapita Selecta Kedokteran, edisi III jilid 2, Media Aesculapius FKUI, Jakarta, 432.

Nainggolan MCD, 2010, Tinjauan Pustaka tentang Status Gizi, Sumatra Utara, Fakultas Universitas Sumatra Utara, (online), (repository usu ac.id./.../chapter\%2011.pdf diakses 16 Agustus 2014).

Notoatmodjo Soekidjo, 2010, Metodelogi Penelitian Kesehatan,PT Rikena Cipta, Jakarta, $124-125$.

Peraturan Menteri Kesehatan Republik Indonesia Nomor 269/Menkes/Per/III/2008/ tentang Rekam Medis, 2008, Jakarta: Menteri Kesehatan Republik Indonesia.

Santoso Henry, Kajian Rasionalitas Penggunaan Antibiotik pada Kasus Demam Tifoid yang di
Rawat pada Bangsal Penyakit Dalam di RSUP Kariadi Semarang tahun 2006, Semarang, Fakultas Kedokteran Universitas Diponegoro Semarang, (online), (eprints.undip.ac.id/8069/1/Henry_Sanrtoso. pdf diakses 10 Januari 2014).

Soepardi Jane, Rosita R, Brahim R, Sitohang, Zulkamaen I, Sunaryadi, dkk., 2010, Profil Kesehatan Indonesia 2010, Kementrian Kesehatan Republik Indonesia, Jakarta, 57 (online),

(www.depkes.go.id/.../PROPIL_KESEHAT AN_INDONESIA_2010.pdf diakses 30 Desember 2013).

Syarif Amir, Estuningtyas, Setiawati, Azalia A, Bahry B, Suyatna FD, dkk., 2007, Farmakologi dan Terapi, Edisi 5, Gaya Baru, Jakarta, 587 - 606.

Tan Hoan Tjay dan Kirana R, 2007, Obat-Obat Penting Khasiat, Penggunaan dan efek Sampingnya, Cetakan Ke-1, PT Alex Media Komputindo Kelompok Gramedia, Jakarta, 65-70; 71-85; 146.

Undang-Undang Republik Indonesia Nomor 44 Tahun 2009 tentang Rumah Sakit, 2009, Jakarta: Presiden Republik Indonesia.

Widyasih Shinta Amalia, 2011, Evaluasi Penggunaan Antibiotik Pada Pasien Pediatri Penderita Demam Tifoid di Instalasi Rawat Inap RSUD Purbalingga Tahun 2009, Fakultas Farmasi Univeritas Muhamadyah Purokerto, Purwokerto, (online), (jhptump-ashintaamal-390-3-babiii.pdf diakses 09 Juli 2014)

Wilianti Novi Praktika, 2009, Rasionalitas Penggunaan Antibiotik Pada PASIEN Infeksi Saluran Kemih Pada Bangsal Penyakit Dalam di RSUP Dr Kariadi Semarang Tahun 2008, Semarang, Fakultas Kedokteran Universitas Diponegoro Semarang, (online), (http://eprints.undip.ac.id/8075/1/Novi_Prati kta_Wilianti.pdf diakses 14 Juli 2014)

WHO, 2003, The Diagnosis, Treatment and Prevention of Typhoid Fever, World HealthOrganization, (online), (whqlibdoc.who.int/hq/2003/WHO_V\&B_0 3.07.pdf diakses 30 Desember 2013) 